Doc. PhDr. Felix Černoch, CSc.

Teorie míru protiváhou vědy o válce

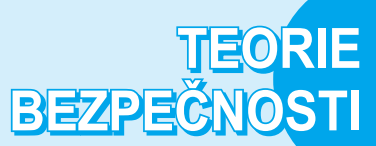

Vojenské rozhledy, 2014, roč. 23 (55), č. 4, s. 133-141, ISSN 1210-3292 (tištěná verze), ISSN 2336-2995 (on line).

Když přestaneme usilovat o mír, tak zůstane navždy mimo dosah. Víme, kam vede cesta, když dáme přednost strachu před nadějí. Odsoudit nebo přehlédnout výzvu ke spolupráci je snadné a zbabělé. Tak začínají války. Tak končí pokrok lidstva.

\title{
Theory of Peace as a Counterweight to War Science
}

\section{Abstrakt:}

Mír je stav ve vztazich mezi státy, národy a lidstvem, charakteristický pokojným a přátelským soužitím, řě̌ením sporných problémů jednáním a dohodou, bez použití ozbrojeného, fyzického násilí nebo psychického nátlaku.

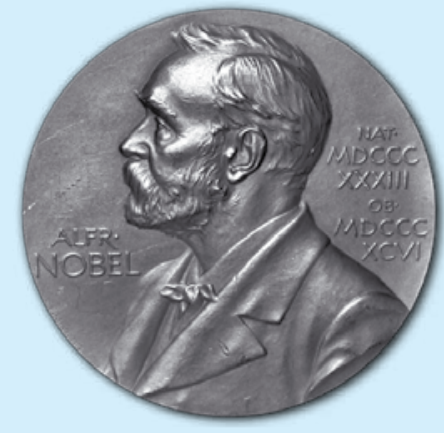

Pro zachování míru je di̊ležité respektování státni suverenity, svrchovanosti, zachováni práva národů určovat vlastni vývoj. Teorie míru, která se těmito otázkami zabývá a již uvádi následující přispěvek, se nazývá paxologie.

\section{Abstract:}

The peace is a state of affairs among states, nations and mankind, characterized by a friendly coexistence, solving matters in dispute by means of negotiations and accords, without use of armed and physical forces or psychological coercion. For preserving peace it is important to respect state sovereignty, independence, the right of nations to define their own courses. The theory of peace, dealing with those items, being introduced by the following article, is called paxology.

\section{Klíčová slova:}

Zachování míru, válka, soužití, jednání, dohoda, fyzické násilí, suverenita, svrchovanost, teorie míru - paxologie, teorie války - polemologie.

\section{Key words:}

Preserving peace, war, coexistence, negotiations, accord, physical force, sovereignty, independence, theory of peace-paxology, theory of war-polemology. 


\section{Prolog}

V minulém - to znamená 3. čísle tohoto (23/55) ročníku Vojenských rozhledů (2014) - zveřejnila Mgr. Petra Průchová podnětnou stat' věcně nazvanou „Kantovo pojetí míru: Spory řešit pokojnou cestou" (strany 64-89). Jde o čerstvou absolventku Vysoké školy mezinárodních a veřejných vztahů v Praze a sukus její zdárně obhájené diplomové práce.

Rád se hlásím k tomu, že jsem ji nejenom inspiroval, nýbrž i vedl. Dodal bych však ještě dvě poznámky $k$ širšímu dobru. Jednak to, že třeba ocenit, když se autorský okruh dané mediální tribuny rozšǐrí o mladší věkové kategorie, ale zároveň i to, zda rozhled vojenský zahrne také dimenzi mírotvorného poslání ozbrojené moci, jak je proklamováno ve stěžejních strategických dokumentech.

Poslední dobou se totiž nejenom znovu a znovu ozývají v různých částech světa zbraně, ale souběžně mluví i jedná o válkách, dokonce možnosti třetí světové, a myslí se to velice vážně. Nejvyšší čas proti tomu se postavit, místo indiferentní registrace, natož pak apologetické podpory takovýchto nepředložených zrůdností.

Nabízená stat' si činí ambice být impulzem, ale zároveň už také startem k rozpracování ucelené nauky, orientované na titulkem zde vymezenou problematiku. Nazývána je pracovně i precedentně paxologii a snad ani není třeba vysvětlovat, proč zrovna takto lapidárně. Každý přece ví, že „pax“ je latinský výraz pro „mír“ a řecká príípona „,-logie“ označuje vědu, která se zabývá tím, co představuje první část složeného slova.

\section{Paxologie}

Bud'me si jisti, že pojmenování není pro vznik vědní disciplíny tím prvořadým, natož aby se to mělo stát věcí ze všech nejdůležitější. Má-li však takový pokus vejít v širši známost, alespoň pro zainteresovanou část odborné veřejnosti, musíme docenit i tuto dimenzi, a mít zároveň na mysli zkušenost, že v jednoduchosti je síla. Odtud výše zmíněná volba. Poněvadž nezadatelným kritériem objektivizovaného poznávání zůstává provždycky pravda, nebojme a nestyd'me se přiznat, že jsou zde ještě jiné pokusy o totéž. Jedním z nich je např́klad irénismus neboli ,úsilí o mír, pokoj, klid, nenásilnost, smíreni" (Nový akademický slovník cizích slov, Academia Praha 2008, strana 365).

Věrnost naznačené otevřenosti však nutí podotknout a zpřesnit, že irénisté se většinou rekrutují z konfesních řad, a tudíž vycházejí z religiózních pozic. Pak pochopitelně nemohou pominout ani Kantův koncept věčného míru, který bychom rádi viděli a chtěli dosáhnout rovněž ve světě i čase reálném.

V každém případě rozhodujícím faktorem zůstává míra vědeckosti náplně koncipovaných oborů, ale zároveň také přesvědčivý tvar, jimž je zpracována. Znamená to vyhranit prvořadě předmět zkoumání, což se tady zdá být jednoznačným již prvopohledově. To samo nestačí, byt' může posloužit za východisko pro rekapitulaci všeho, co bylo na dané téma nastřádáno v dosavadním vývoji lidského poznání.

$\mathrm{K}$ tomu se bude nutno vrátit, nebot' právě odtud mohou vzejít i klíčová slova, či přesněji řečeno, stěžejní pojmy. S nimi se pak dá operovat a dospět k sumarizaci pojmosloví respektive taktéž definování kategorii čili jádru vědosloví. 


\section{Předpoklady vědeckosti}

Nastolujeme tak otázku, co je vlastně věda, kde a kdy začíná? Co lze za ni považovat a co nikoliv? Kterak se nějaké učení mění v nauku a za jakých okolností se ona proměna děje či jaké podmínky musí být přitom splněny?

Podle obecně respektovaného náhledu jde o trojrozměrnou potřebu resp. její pokrytí:

口 nezbytnost existence vědeckého problému, tj. skutečnosti dosud uspokojivě nevysvětlené,

$\square$ nezbytnost aplikace vědecké metody, tedy vedení přesvědčivé argumentace skrze důkazy,

nezbytnost formulace vědeckých závěrů, tzn. odhalených zákonitostí studovaného jevu.

\section{Podoba vědy}

Jak tudíž pojednávanou kategorii vědeckosti pojímat a čím vědu oslovit? Čím se pak ona hodlá zabývat a jak se to chystá řešit? Opět se nabízí odpověd' až podezřele jednoduchá:

Vědou rozumíme teorii předmětu, který je jí zkoumán! Onou teorií se potom rozumí odhalování zákonitostí sledovaných dějů, neboli hledání a dokazování toho, co platí nezvratně, vždy a všude, v rámci definovaného řádu př́ipadně jeho výjimek.

\section{Předimět zkoumání}

Je-li je v paxologii už ted' něco naprosto nesporného a jednoznačného, dá se to vyjádřit naprosto lapidárně jediným slovem a hodnotou - mír! Protože věda se musí stále ptát, klade si další a další otazníky dokonce i tam, kde považuje věci za již dořešené.

Začněme výhradou, podle níž se mírem už i tak zabývá erudovaně spousta pozitivních, dávněji existujících věd; zejména společenských, či chcete-li - sociálních anebo humanitních. Proč tedy ono vyhraňování v další vědní obor?

Zdůvodněním budiž předsevzetí pojímat mír jako svou ústřední kategorii, kdežto pro ty ostatní je záležitostí toliko marginální. Zabývají se jím jen tam a tehdy, když to koresponduje s jejich generální orientací.

Kromě naznačené koncentrace na mír jako centrum své pozornosti, ji charakterizuje navíc ještě komplexnost nazírání, což v takové úplnosti nečiní žádná jiná věda; jednak na to nemá, a jednak ji to až tolik nezajímá.

Jestliže se těmito dvěma pohledy žádný jiný obor nezabývá a zabývat nehodlá, opodstatňuje to právo paxologie na samostatnou existenci a sebeprosazování. Tím se ovšem zároveň stává nenahraditelnou a nezastupitelnou. 


\section{Cíle snažení}

Vymezení předmětu vědní disciplíny znamená, i přes její nerozvinutost či jistou nepropracovanost, nárok na systémové začlenění mezi ostatní. Zejména, pokud si souběžně s tím zakládá kategoriální aparát, když mír tu představuje netoliko předmět, jenž se tu podrobuje zkoumání, leč tvoří hned i stěžejní oborovou kategorii.

Tím se už dostáváme k vlastním teoretickým základům odvětví, jež přichází s ambicí konstituování v novou, leč uznávanou nauku. Má-li se paxologie takovou stát, musí přijít s tvorbou ucelené teorie míru, což znamená i předpokládá odhalit a precizně formulovat jeho zákonitosti. To si vytyčit jako první kontrolní metu autoreflexe. Nepochybně se musí při tom vymezovat mír proti válce ve vzájemné konfrontaci jejich teoreticky odlišných výrazů.

\section{Války ano - mír ne?}

Faktem je, že válka již svůj vědní obor hodně dávno má (nazývá se polemologie), kdežto mír ve srovnatelných podobách dosud nikoliv. Proto mají ozbrojené konflikty nejenom své apologety či vykladatele, nýbrž taktéž osnovatele a fundované organizátory. A to je ze všeho nejnebezpečnější! Zvláště dnes, kdy ono konání je vrcholně poučeným až instruovaným.

Představme si stejnou oporu pro ty, kteří proklamují mír a činně se o něj zasazují. Jak užitečnou investicí do jejich erudice by to bylo. Přitom v sázce je vskutku mnoho, jen si věci připustit a jednat. Nejde o počinek malý a rozhodně i méně stojí. Čímž se ovšem nemíní jen množství vynakládaných prostředků a vyčleňovaných kapacit.

Tvrdí se, že praxe je bez teorie slepou, a proto tak často tápe. A tady jde o přiliš vážné věci, než abychom je nechali napospas metodám typu ,pokus-chyba“. Právě proto se ř́ká o mírových jednáních či také jiných aktivitách, že jsou to prázdná slova. V souhlasu s Hegelovým výrokem, že nejpraktičtější je dobrá teorie, lze pak tímto instrumentářem vyzbrojit všechny, kdož brojí proti zbrojení a zbraním, brání mír a jsou odhodláni ho i budovat a opevňovat v dobytých pozicích. Bez teoretické výzbroje to ovšem půjde asi stěží. Další hlas pro konstituování teorie míru či budete-li to již akceptovat-paxologii.

\section{Jednostranná retrospektiva}

Traduje se, že dějiny jsou historií válek. Nic proti tomu. Nedá se to zpochybnit. Nepopíratelně se válčilo, takže dějiny jsou taktéž historií válek. Leč zvažme: probíhá-li válka, musí existovat nezvratně a zcela zákonitě taktéž její protipól. Tím jest mír. Před každou válkou, a rovněž po každé z nich. Byt' jen krátce a bez ohledu na jeho cenu nebo i podobu. Platí tu zákon Aristotelovy formální logiky o vyloučeném třetím, tj. dvě strany téže mince.

Držme se tudíž jen faktu, že se válka objevuje a zase mizí. Jde tu však spíše o stř́idání války s mírem či výstižněji řečeno - míru s válkou. Budeme si proto nadále všímat už jen míru a začneme konstatováním, že dějiny jsou rovněž historií míru. Byt' mezi oba jevy tím ani zdaleka neklademe hodnotové rovnítko. 


\section{Definiční obory války a míru}

$\mathrm{Z}$ jedné strany, třeba sémantické, lze přece jen účelově připustit interpretaci míru jakožto stavu či prestávky mezi válkami neboli jinak též jako klid zbraní. Stejně můžeme ovšem považovat válku za přerušený mír či stav mezi obdobími klidu zbraní, nahrazovanými jejich řinčením. A bez klidu nemůže být neklidu, to možná spíše naopak.

Odvozeně se poučme ze situace, kdy múzy mlčí a kdy ne, respektive proč tomu tak je. Zda jde o mlčení mezi jejich činorodostí nebo příznačně intenzivní projevy mezi mlčením. Čas míru proti času války, neválčení proti válčení. Pauzu jednoho mezi druhým, druhým pak mezi prvním. Vážit, čeho jest více, co trvá déle, probíhá intenzivněji, ale hlavně - přináší větši prospěch a komu, zakládá užitek a jaký, pro koho.

\section{Podstata války a míru}

Díky existenci vojenských věd, jimiž je rozpracovávána teorie válek, zdědili jsme nejenom jejich definici a formulaci podstaty, nýbrž i odrazový můstek pro stejnorodé a rovnocenné posouzení míru. Je-li válka pokračováním politiky jinými, totiž násilnými prostředky, potom platí, že mír je politikou vedenou nenásilnými prostředky.

Při absenci vědy o míru - po jejímž konstituování zde voláme - nám podobná definice citelně schází, a tak nezbývá, než se přiživit na tom, co už tu pregnantně vyjádřeno je. Navíc všeobecně též prijímáno. Věcně si onen živý odkaz proto dovolujeme vypůjčit, a dokonce poněkud převrátit.

\section{Politikum věci}

Vážeme-li mír stejně jako válku na politiku, nezbývá nic jiného, než si ujasnit a vyhranit rovněž její vlastní definiční obor. Někdo ji totiž ztotožňuje s činností lidí u moci, což ovšem nelze zcela odmítnout. Rozhodně ji však nebudeme redukovat na sebevlivnější akty jednotlivců, at' jakkoliv mocných. Viz Ludvík XIV. s jeho slavným výrokem Stát jsem já!, anebo taktéž Hitlerovou vůdcovskou vůli, jejímž prostřednictvím se prosazovala „Prožretelnost“".

Přikláníme se k vymezení, že v ní jde o harmonizaci vztahů mezi velkými skupinami lidí - tedy státy, národy, etniky, tř́dami, generacemi, náboženskými pospolitostmi, věkovými, sociálními, profesními skupinami apod. Každý z těchto subjektů společenského dění vznikal vždy z nějakých potřeb a prosazuje takto své specifické zájmy. Ty se tu scházejí či zase naopak liší, stojí vedle sebe př́ípadně ostře proti sobě, takže nutno je slad'ovat. Právě to je rolí, posláním, určením, ale i údělem politiky! Zrovna o tom v našem náhledu politika jest a zrovna o to v ní všude pořád jde.

\section{Není mír jako mír!}

Tak jako u kteréhokoliv jevu, musíme i tady poměrně př́ísně diferencovat případ od př́padu. Ty jsou sice každý jiný, ale všechny dohromady přece jen vyjevují určité 
zákonitosti, které jim jsou společné. Proto rozlišujeme různé podoby míru, když není jeden jako druhý. Každý je asi něčím příznačný, nějak jedinečný, má své specifické důvody, příčiny, projevy, rysy. Záleží tudíž jenom na kritériích, podle nichž budou moci být tříděny - klasifikovány.

\section{Mír není prázdným slovem}

Výše uvedeným tříděním - klasifikací -, se dostáváme již pod povrch zkoumaného jevu v realitě, řekněme jeho jakési kategorizaci. Přijde na vytvoření kategoriálního aparátu, kterým to chceme učinit. Jeho pomocí a prostřednictvím totiž dospíváme k tomu nejpodstatnějšímu pro každou vědu - paxologii nevyjímaje.

\section{Charakter míru}

Pokusů o postup tímto způsobem a směrem bylo snad bezpočet, přičemž se nedá poprrít, že měly často úspěch. Zejména tam, kde se opíraly o průkazné třídící znaky, čímž se jim dostalo nejenom uznání, ale i puncu obecné přijatelnosti. Proto mohou i nám posloužit za východisko zkoumání zákonitostí míru či dokonce prrímo vstupovat už i do rodící se vědy o něm.

Naprríklad v encyklopedii Diderot máme co činit hned s několika př́stupy k rozlišování různých podob míru čili jeho druhového členění podle charakteru. Minimálně může být silnou inspirací a následování hodným impulzem:

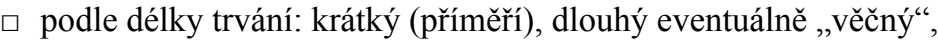

๑ podle územního rozsahu: lokální, regionální, kontinentální, globální,

$\square$ podle míry účinnosti: totální (absolutní, naprostý, úplný), parciální (omezený, dílčí, částečný), dočasný (příměří),

口 podle způsobu dosahování: vnucený nebo přijatý, vybojovaný nebo darovaný,

$\square$ podle daných garancí: smluvní nebo nestvrzený, precedentní nebo bezprecedentní,

$\checkmark$ podle dojednaných podmínek: výhodný či nevýhodný, a to jednostranně či oboustranně,

$\square$ podle výsledného efektu: podmíněný nebo bezpodmínečný resp. kompromisní či nekompromisní.

\section{Kterak to všechno zkoumat}

Představená dešifrace charakteristik míru v jeho různosti se společnými jmenovateli je zároveň pro nás jakýmsi pracovním itinerářem či chcete-li, tak cestovní mapou po teritoriu, kde by měl vládnout klid nejen zbraní, ale cílově dokonce úplně a definitivně bez nich.

Tím se však současně noříme do metodologie, která je přece pro každý z vědních oborů páteří, a to naprosto bez výjimek. Ta se mu pak zpevňuje především pojmotvorným procesem, protože pojmosloví představuje více než pouze odrazový můstek pro přeskok rovnou do vědosloví, skoro či spíše jeho spolehlivý základ. 
Z aristotelovské logiky přece dávno víme, že pojem představuje souhrn podstatných znakủ toho, co symbolizuje, co pod daným pojmenováním pojímáme. Jenom dodejme, že ho musíme vnímat prioritně jako součást reality. Teprve potom v proměnách odrazů již z toho prostého důvodu, že ty jsou vždycky chudobnější než ona sama ve svém nekonečném propojení všeho se vším.

Jinak pro zopakování a sebeutvrzení lapidárně řečeno - mezi pojmem a slovem neleží rovnítko. Rozlišujeme totiž mezi složkou ontologickou neboli věcí či jevem o sobě - existenčně, bytím - a jejich terminologickým vyjádřením, to znamená složkou tzv. nominální čili rozměrem normativním.

\section{Instrumentárium}

Metodologickým základem tu nemůže asi být nic jiného než filozofie. Ale ta sama na vše nestačí a zvládnout ani nedokáže. Proto je nutný její přesah k pomocným aplikačním oborům resp.vědám a čerpat $\mathrm{z}$ nich kromě poučení především nástroje systémového rozpracovávání sebe samé. Určitě tu najdou velké uplatnění postupy výzkumů historických, politologických, sociologických ... asi vůbec všech společensko-vědních, když se tady v př́ípadě míru, stejně jako války, jedná primárně o jev povahy sociální.

Zřejmě se dá předpokládat, že převahu zde budou mít metody přejaté. To však nikterak nevylučuje potřebu se hledat (třeba jen pro začátek) v metodách odvozovaných či inspirativně vyvozovaných. Závisle na intenzitě nasazení a poctivosti bádání, jeho širre i hloubky.

\section{Od teorie k praxi, od praxe $\mathrm{k}$ teorii}

Věda ovšem nemá účel sama v sobě, ale ve společenské užitečnosti. Je pak vlastně servisní povahy či přehnaně nadsazeno - až „sociální službou“. Nelze se pak divit, že de facto i teorii musíme považovat za imanentní součást praxe. Nestojí mimo ni, o to méně dokonce proti ní, jak někdo někdy někde falešně vyvozuje. Jednak se děje $\mathrm{v}$ rámci společenské praxe a prostřednictvím osob evidentně do ní zakotvených, které z ní čerpají podněty, a takto poznávané potřeby také uspokojují. Naznačený cyklus tudíž zakládá koloběh o němž je tady řeč a do něhož se chceme svou troškou začlenit ve prospěch teorie i praxe míru.

Máme-li proto být a zůstat věcně konkrétními už zde a v tuto chvíli, préedestíráme stručný výběr z pojmosloví, které se nachází zrovna poblíž zmíněného rozhraní. Jsou to velice důležité, a zároveň i frekventované pojmy jako je obhajoba, obrana, prosazování, budování, upevňování, zajištováni míru ..., které se sice často vyslovují, a dokonce s vazbou na realizační snahy, avšak v definičním vymezení zaostávají. Př́íklad, kdy je praxe bez teorie slepou a tápe, př́ípadně se mýlí a činí chyby.

Zároveň ale doklad, jak se teorie vyhne samoúčelnosti a formalismu, předejde jisté akademizaci, a najde svými výstupy rychlé uplatnění v životě.

$\mathrm{Nu}$ a stačí navázat na vyřčené, abychom zauvažovali ještě i v opačném gardu. Co dějů probíhá, které prrímo volají po svém vysvětlení, objasnění zákonitosti či aspoň zobecnění zkušeností ne-li generalizaci vědecké. Pro ilustraci uved'me mírové hnutí, mírové 
konference a kongresy, mírové mise , mírové operace, mírové sily, mírové sbory, mírové organizace, mirové výbory či komitéty, mírové svazy, mírové rady ...

Minimálně to budiž apelem pro tvorbu alespoň terminologického slovníku, př́ípadně metodické př́ručky pro mírové aktivisty, nebo i politiky, kterým se to stalo posláním a mohou mít na chod věcí vliv. Rozhodně se dá odtud začít a sestavit jakýsi Lexikon míru, velice užitečný pro praxi, ale už i s charakterem vstupenky do světa vědy. Poněvadž vědeckým puncem bývá dosti často transformace vznikající disciplíny ve vysokoškolský předmět anebo aspoň vzdělávací kurz, měl by hned $\mathrm{k}$ dispozici přinejmenším studijní oporu - suplementum, snad jako pramennou literaturu.

\section{Kudy kam dále?}

Otázky $\mathrm{k}$ řešení se nabízejí samy a $\mathrm{v}$ řetězcích. Co třeba takhle bádání o ceně války a ceně míru? Názory, že válčení posouvá technologický pokrok a touto cestou i blahobyt společnosti, jsou míněny vážně, a třeba i s dávkou vědecké apologetiky.

Souvisí to těsně i s dilematem, zda odzbrojení či jen kontrola zbrojení resp. když odzbrojování, tak jestli všeobecné a úplné nebo jen pro někoho a částečně.

Když mír - čím ho dosáhnout a zaručit - či jaký mu dát ráz? A to nemluvíme o podílu vědeckých platforem na mírotvorných snahách, počínaje kongresovou tematikou, přes bojkoty zbrojních programů či odsudky vojenských eskapád. Viz pugwashské hnutí založené roku 1955 kanadským miliardářem Eatonem a spuštěné memorandem, jež sepsali společně Albert Einstein s Bertrandem Russelem jako výzvu citovaného druhu. Funguje dodnes a škoda, že bez našeho zastoupení. Skončilo úmrtím brněnského prof. Jiř́ho Matouška, plukovníka v. v., a světově respektovaného znalce problematiky zbraní hromadného ničení, proti nimž vystupoval.

Cožpak je nutno k tomu něco ještě dodávat? Snášet na podporu další argumenty, když těmto snad na přesvědčivosti zase tolik scházet nemohlo? Nicméně odpovězme závěrečným zamyšlením resp. formulací rovnice k zadumání veřejnému i utajenému, kvalifikovanému i laickému.

\section{Závěrem: Perspektivy světa}

Stačí se ptát zcela triviálně, zda je lepší být, či nežit? Kdo by tu s jednoznačností odpovědi váhal, když by se mělo jednat o jeho individuální osud? A přece titíž jedinci sídlící v „radách bohư“", kde se rozhoduje vlastně o tomtéž, klidně své názory odsouvají, ale co horšího - diametrálně otáčejí zaujímané postoje.

Sestupme nyní pro změnu do nižšího patra, abychom se ptali prostých lidí, zda svět beze zbrani je $\mathrm{v}$ předestřené souvislostí reálnou nadějí, nebo iluzí. Ale záměrně ji tu ponechme otevřenou. At' se mohou vyslovit učenci, a třeba i nevzdělanci, osoby agilní a stejně i neteční pasivisté.

Stačí snad připomenout kardinální rozpornost na tomto poli, jíž se stala skutečnost, že hypertrofie prostředkủ vedení válek vyvolává nutně atrofii jejich funkce. To nelze pominout a přehližet, nebot' válka se vskutku proměnila na tak ničivou, že ztrácí na smyslu a přestává být fakticky možnou! Vylučovat proto její nutnost a poukazovat 
na cesty eliminace ozbrojených konfliktů vưbec - berme za historický úděl i pro vědu, která vládne účinnějším arzenálem než si připouští. $Z$ toho chceme odvozovat i přesvědčení vyjádřitelné programovým heslem: Paxologie do služeb míru!

\section{Použitá literatura a prameny:}

ČERNOCH, F. Nezanedbatelné dimenze války i míru: Ekofilozofie, paxologie. Vojenské rozhledy, 2013, roč. 22 (54), č. 1, s. 41-45, ISSN 1210-3292 (print), ISSN 2336-2995 (online). Dostupné na http:// www.vojenskerozhledy.cz/ke-stazeni-v-pdf.

OBAMA, Barack. Zbavit se jaderných zbraní? Yes, we can! HN.Ihned.cz, 6. 4. 2009, dostupné na http:// hn.ihned.cz/2-36629230-500000_d-5c.

Slovnik vojenského profesionála: Humanitni obory. Ed. redakční útvar encyklopedické a slovníkové literatury HÚ AČR, Praha: MO ČR, 1993, 272 str., bez ISBN.

Všeobecná encyklopedie v osmi svazcich. Sv. 1-8 / General Encyclopedia in Eight Volumes. Vol. 1-8, Praha: Diderot, 1999, ISBN 80-902555-2-3.

Války jsou staré jako Evropa sama. Náš světadíl zjizvily kopí a meče, kanony a pušky, zákopy a tanky, a nejen ty. Přesto všechno po dvou zkázonosných válkách, které náš kontinent a s ním i zbytek světa zasáhly zavládl v Evropě konečně trvalý mír. $\mathrm{V}$ té ponuré době ležela města $\mathrm{v}$ troskách a $\mathrm{v}$ srdcích mnohých stále vládl zármutek a zášt'. Jak obtížné se tehdy zdálo, slovy Winstona Churchilla, „začít se znovu radovat z obyčejných věcí a věřit, že stojí za to žít“.

Od zakladatelů Evropy bylo tedy velmi odvážné prohlásit, že můžeme prolomit tento nekonečný kruh násilí, zabránit touze po pomstě a společně vybudovat lepší budoucnost. Jak velkou představivost museli mít! Samozřejmě, mír mohl být v Evropě i bez Unie. Je to možné, ale to se nikdy nedozvíme. Nikdy by však neměl stejnou povahu. Nebyl by to trvalý mír, ale chladné příměří. Osobně na tomto míru považuji za jedinečné smíření. V politice, tak jako v životě, je smíření tou nejtěžší věcí. Je to více než odpuštění a zapomnění či jen obrácení stránky. Pomysleme, čím prošla Francie a Německo a pak učinily tento krok, podepsaly smlouvu o prátelství.

Mír je nyní samozřejmý a válka naprosto nepředstavitelná. „Nepředstavitelná“ ale neznamená „nemožná“. A proto jsme se zde dnes sešli. Evropa musí dodržet svůj slib míru. Domnívám se, že to je základní cíl naší Unie. Evropa se nemůže dále spoléhat, že jen díky tomuto slibu osloví občany. Ano, je to v pořádku, protože vzpomínky na válku blednou. Ale zatím ne všude. Sovětská nadvláda nad východní Evropou skončila před pouhými dvaceti lety. Krátce poté došlo na Balkáně k hrozným masakrům. Dětem, které se narodily v době událostí v Srebrenici, bude příští rok jen osmnáct. Jejich mladší sourozenci se však narodili už po této válce, a to je první skutečná poválečná generace v Evropě. A musí to tak zůstat.

Kde byla válka, je nyní mír. Před námi však leží další historický úkol: kde je mír, tam ho udržet. Dějiny přece nejsou žádný román, žádná kniha se št’astným koncem, kterou můžeme zavř́it. Stále máme plnou odpovědnost za naši budoucnost.

Z děkovné řeči Hermana Van Rompuye, předsedy Evropské rady, u příležitosti udělení Nobelovy ceny míru Evropské unii 10. prosince 2012. 